\title{
An unusual case of sepsis? A rare presentation of a common disease
}

\author{
Christopher Myles Rowe, ${ }^{1}$ Nishita Desai, ${ }^{2}$ Rachel Coathup, ${ }^{3}$ Magda Cepkova ${ }^{1}$
}

${ }^{1}$ Intensive Care Unit, The Whittington Hospital, London, UK

${ }^{2}$ Intensive Care Unit, St Mary's Hospital, London, UK

${ }^{3}$ Department of Anaesthetics, Barnet General Hospital, London, Hertfordshire, UK

\section{Correspondence to} Dr Christopher Myles Rowe, net.uk

Accepted 7 August 2015 christopher.m.rowe@doctors.

\section{DESCRIPTION}

A 22-year-old Algerian man attended hospital with a 20-day history of non-specific abdominal pain and vomiting. Concurrently, the patient reported non-intentional weight loss and fevers/night sweats, but denied any neurological, respiratory or cardiovascular symptoms. The patient had an extensive travel history throughout North Africa and Europe.

Clinical examination revealed general upper abdominal and bilateral flank pain. Respiratory, cardiovascular and neurology examinations were normal. Vital observations revealed fever of $39.3^{\circ} \mathrm{C}$, but were otherwise normal. Initial blood tests demonstrated an elevated $\mathrm{C}$ reactive protein (CRP) of $92 \mathrm{mg} / \mathrm{L}$, but normal white cell count and full blood cell count, liver function tests, and urea and electrolytes. The serology for HIV was negative. Admission chest X-ray was normal. CT of the abdomen/pelvis was undertaken: a large paravertebral, septated collection (figure 1A) and scalloping of the T10 and T11 vertebrae were demonstrated. A subsequent CT of the chest revealed cranial extension of the previously described paraspinal collection to the level of
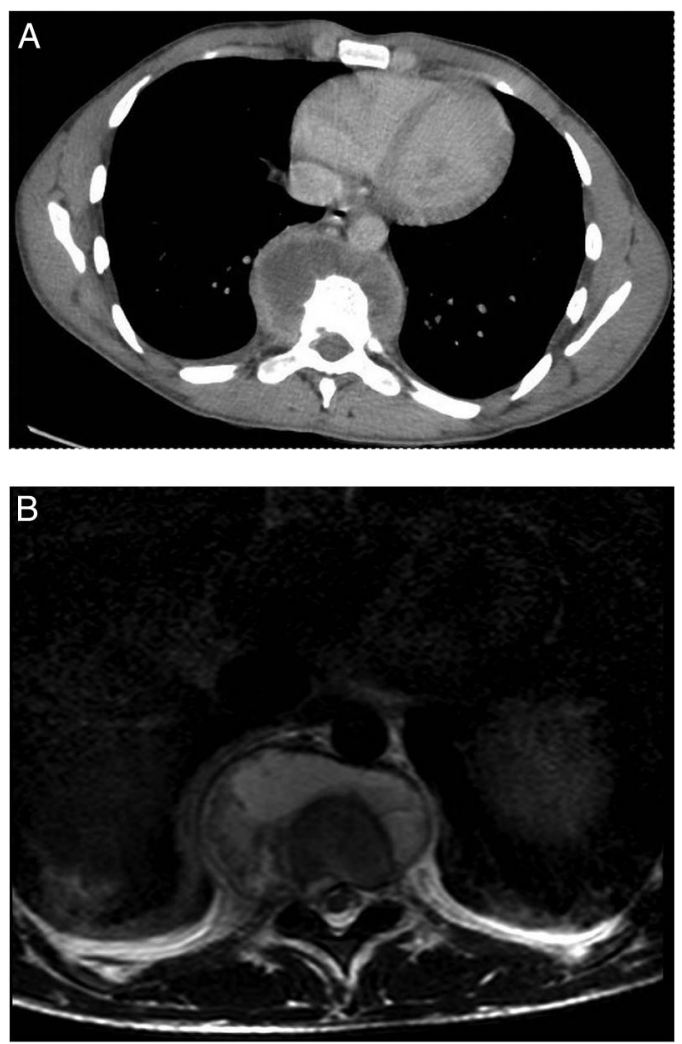

To cite: Rowe CM, Desai $\mathrm{N}$ Coathup $\mathrm{R}$, et al. BMJ Case Rep Published online: [please include Day Month Year] doi:10.1136/bcr-2014207698

CrossMark
Figure 1 (A) Axial CT and (B) axial T2-weighted MRI demonstrating a large, septated prethoracic vertebral abscess. Anterior displacement of the oesophagus is illustrated. the T6/7 disc space (figure 2A). A 10-french pigtail drain was placed under CT guidance: PCR of the drained fluid revealed Mycobacterium tuberculosis DNA and standard quadruple M. tuberculosis treatment (encompassing pyrazinamide, isoniazid, ethambutol and rifampicin) was started. Later, M. tuberculosis culture revealed full sensitivity to the four chemotherapeutic agents. MRI of the thoracic and lumbar spine illustrated a large multilocular perivertebral abscess (figures $1 \mathrm{~B}, 2 \mathrm{~B}$ and 3 ), but no spinal cord compression.

Two days after starting standard quadruple M. tuberculosis therapy, the patient deteriorated haemodynamically with fever, hypotension and tachycardia, requiring intensive care unit admission for aggressive fluid resuscitation, however, inotropes were not required. The white cell count elevated to $25.1 \times 10^{9} / \mathrm{L}, \mathrm{CRP}$ to $233 \mathrm{mg} / \mathrm{L}$ and lactate to $3.5 \mathrm{mmol} / \mathrm{L}$ despite fluid resuscitation. Clinically,
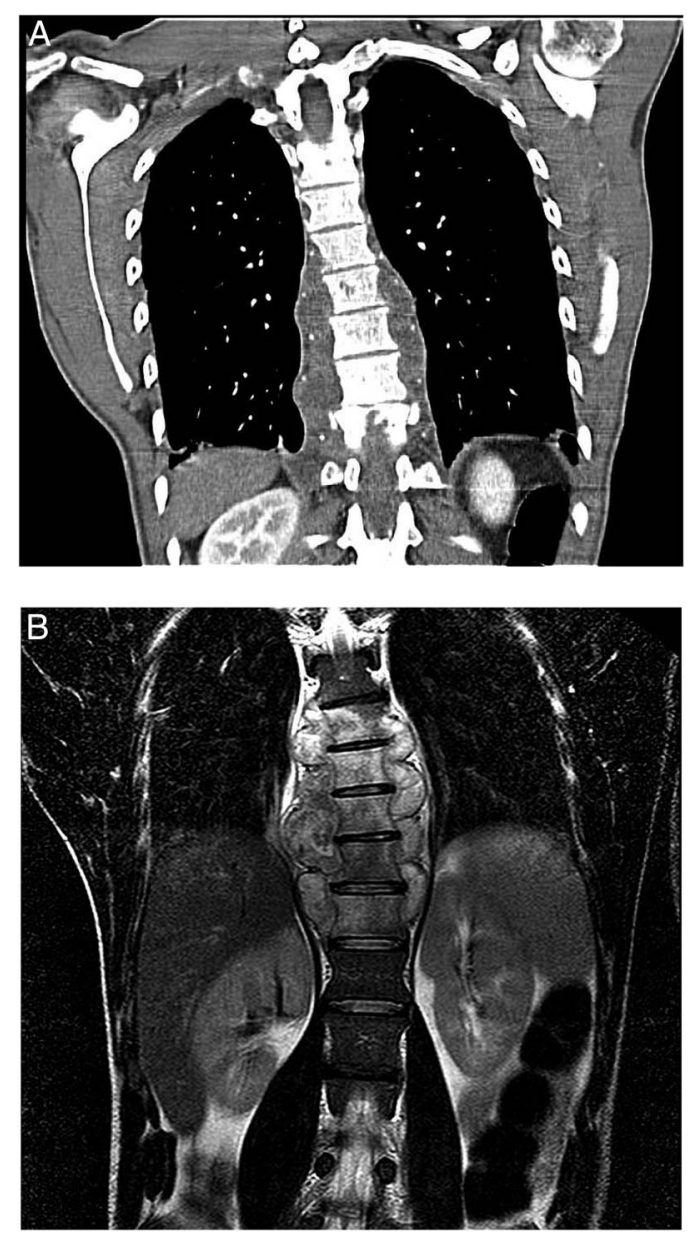

Figure 2 (A) Coronal CT and (B) coronal T2-weighted MRI illustrating a paravertebral abscess of the lower thoracic vertebrae. 


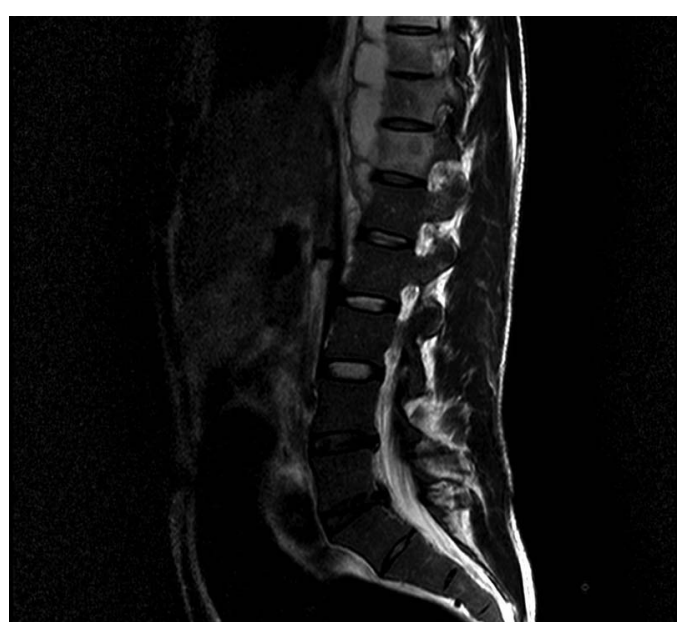

Figure 3 Sagittal T2-weighted MRI demonstrating a prevertebral abscess of the lower thoracic and lumbar vertebrae; anterior displacement of the anterior vertebral ligament is illustrated.

the patient reported malaise and fevers, but systemic examinations were normal and a septic screen (encompassing a chest $\mathrm{X}$-ray, and blood, sputum and urine cultures) was negative. Multidrug resistant/extensive-drug resistant $M$. tuberculosis (sensitivities were not known at this time), a paradoxical response to the M. tuberculosis treatment, an unidentified source of bacterial sepsis or M. tuberculosis sepsis were differential diagnoses.

More than 2 billion people worldwide are infected with M. tuberculosis, including 9.3 million new cases and 1.7 million fatal cases per annum. ${ }^{1}$ It is postulated that $M$. tuberculosis sepsis pathophysiology is mediated by lipoarabinomannan, a component of the M. tuberculosis cell wall, which stimulates tumour necrosis factor while inactivating macrophages. ${ }^{2}$
In light of the haemodynamic changes, proximity of the M. tuberculosis abscess to the central nervous system and nonspecific symptoms potentially indicative of $M$. tuberculosis meningitis, the patient was treated with high-dose steroids. After continued standard quadruple $M$. tuberculosis treatment and abscess drainage, the patient improved and was discharged.

\section{Learning points}

- Mycobacterium tuberculosis sepsis is rare, especially in immunocompetent patients; it occurs most often in immunocompromised patients, notably patients with HIV. ${ }^{2}$

- Initiating M. tuberculosis chemotherapy can evoke worsening of disease or new lesions, termed paradoxical reactions, postulated to be due to the liberation of tuberculoproteins. ${ }^{3}$

Acknowledgements The authors would like to thank Dr Rosalind Crooks (consultant radiologist) for her advice and teaching around the images.

Competing interests None declared.

Patient consent Obtained.

Provenance and peer review Not commissioned; externally peer reviewed.

\section{REFERENCES}

1 Kethireddy S, Light RB, Mirzanejad Y, et al. Mycobacterium tuberculosis septic shock. Chest 2013;144:474-482.

2 Bridges DA, Bedimo RG. Severe tuberculosis sepsis in an immunocompetent patient. Am J Med 2006;119:e11-14.

3 Breen RA, Smith CJ, Bettinson $\mathrm{H}$, et al. Paradoxical reactions during tuberculosis treatment in patients with and without HIV co-infection. Thorax 2004:59:704-7.

Copyright 2015 BMJ Publishing Group. All rights reserved. For permission to reuse any of this content visit http://group.bmj.com/group/rights-licensing/permissions.

BMJ Case Report Fellows may re-use this article for personal use and teaching without any further permission.

Become a Fellow of BMJ Case Reports today and you can:

- Submit as many cases as you like

- Enjoy fast sympathetic peer review and rapid publication of accepted articles

- Access all the published articles

- Re-use any of the published material for personal use and teaching without further permission

For information on Institutional Fellowships contact consortiasales@bmjgroup.com

Visit casereports.bmj.com for more articles like this and to become a Fellow 